\title{
The Process of Catching up with the Economic Development of OECD Countries and the Role of Foreign Direct Investment in this Process
}

The article consists of two parts. In part one we describe the level of economic development of 51 countries associated with the Organization for Economic Cooperation and Development (OECD) in terms of their GDP per capita. We suggest dividing these countries into three groups: highly, moderately, and least developed. Then, using the average annual growth rate in the period 2005-2016, we distinguish countries: developing, in stagnation, and in recession. Combining these two variables, we propose to distinguish 7 subgroups of countries: from highly developed fleeing, through highly developed stable and caught up countries to the countries medium and least developed that are catching up.

In part two of the article we analyze foreign direct investment (FDI) in global terms, OECD countries, and the European Union (EU); in particular we examine capital flows between the previously specified three (high, medium and least developed) groups of OECD countries. Finally, we present regression models confirming the positive feedback between FDI and economic growth. They testify to the pro-cyclical impact of foreign direct investment.

Keywords: Highly, Moderately and Least Developed Countries; OECD Countries; Countries Fleeing, Catching up and Caught up; Foreign Direct Investment.

\section{Introduction}

The New Structural Economics (NSE) is a theoretical base of the economic policy of the state supporting economic growth, mainly dedicated to the catching-up economies ${ }^{1}$. Catching up is an attribute of any racing competition.

1 This is evidenced by the title of the article by J.Y. Lin "Nowa Ekonomia Strukturalna dla gospodarek doganiających” (New Structural Economics for catching-up economies) (cf. Lin, 2017). 


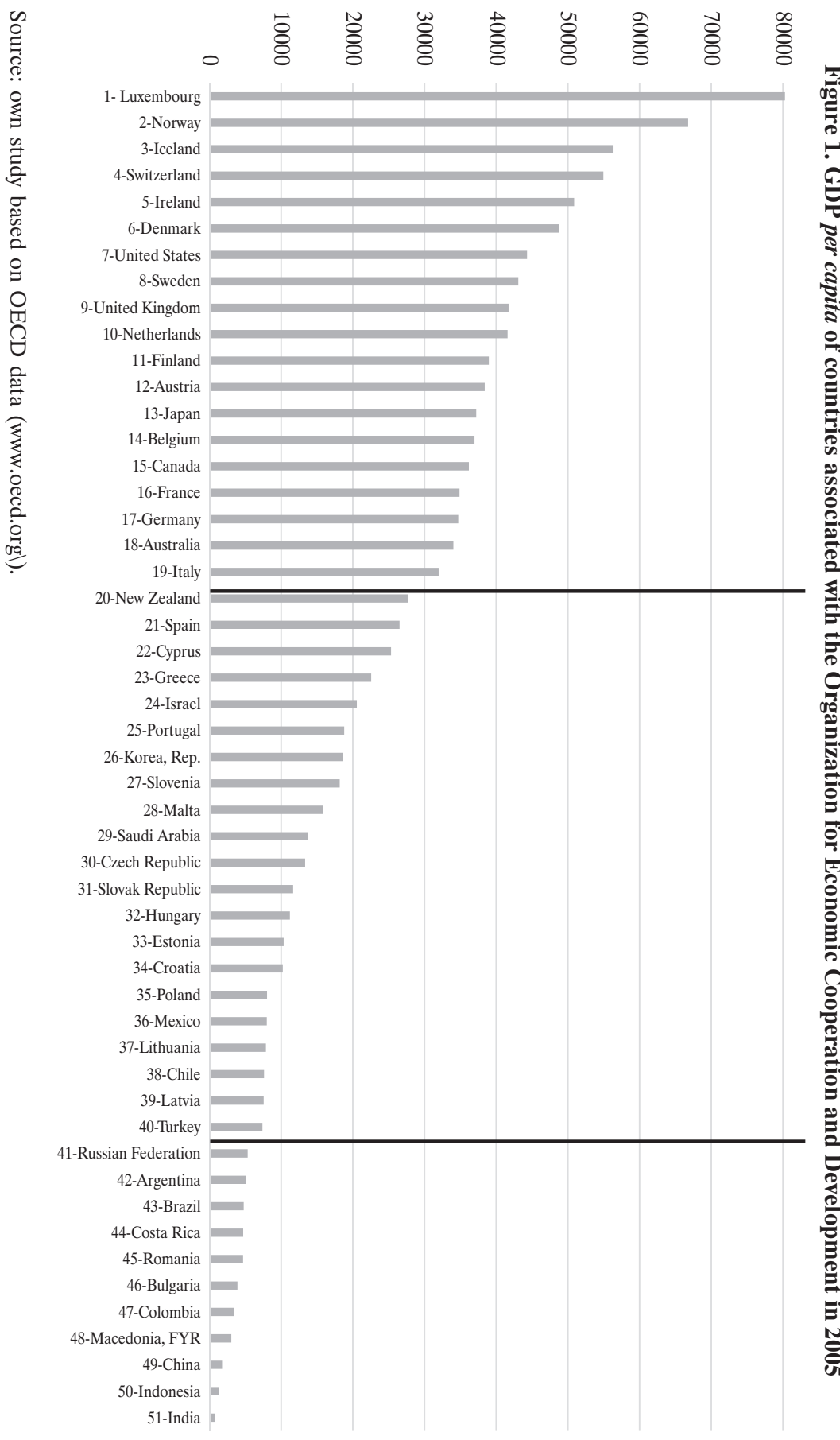

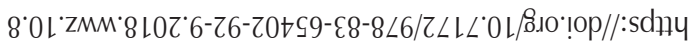


This prompted us to examine how this race of countries catching up with the leaders - the most developed ones - looks like. The analysis is limited to the database of 51 countries associated with the Organization for Economic Cooperation and Development (OECD). This is a type of sports report from the race in which these countries compete in the process of economic development occurring in the period 2005-2016.

Countries associated with the OECD have different statuses. 36 countries have the status of a member. Poland joined this Organization in 1996. Eight countries aspire to membership in the OECD (e.g. Russian Federation), other countries included in the study have signed agreements for enhanced cooperation (https://data.oecd.org). Belonging to the OECD is a certain ennoblement for the state concerned and has an unquestionable impact on its risk assessment and rating 2 . The full list of countries included in the survey is shown in Figure 1.

\section{Degree and Rate of Development of OECD Countries}

As the only measure of the level of economic development of a country we accept Gross Domestic Product per capita (GDP per capita). We are aware of its informative limitations, but there is no other similarly synthetic indicator. Figure 1 shows the level of GDP per capita in OECD countries in 2005, that is at the start of the race. It must be admitted that the spread of levels of GDP per capita is very high. The highest - 80,000 USD is in Luxembourg, the lowest is 707 USD in India. We offer the division of OECD countries taking the GDP per capita into consideration, into three groups:

- 19 highly developed countries with GDP per capita ranging between 30-80 thousand USD,

- 21 moderately developed countries: GDP per capita in the range of 5-30 thousand USD,

- 11 least developed countries - GDP per capita 0.700-5 thousand USD.

In the first group, 6 countries with the highest level of GDP per capita deserve attention: Luxembourg - 80,000 USD (position 1), Norway - 68 thousand USD (position 2), Iceland - 58 thousand USD (position 3), Switzerland - 55,000 USD (position 4), Ireland - 50,000 USD (position 5), Denmark - 49,000 USD

2 Before the Basel II adoption, a risk weight of 0.2 was used to calculate the solvency ratios of banks for claims from financial institutions operating in OECD countries, while for others the risk weight was 0.5 . 
(position 6). These countries, it seems, have something in common. They are relatively small West European countries that have a centuries-long tradition of a capitalist economy, have avoided the ravages of war, in particular losses suffered in the World War II. The United States is in $7^{\text {th }}$ place (42,000 USD), and Germany is $17^{\text {th }}$ (35,000 USD). The group of the most developed countries ends with Italy (31,000 USD).

The second group of moderately developed countries begins with New Zealand (28,000 USD), with Turkey ranking last (7,000 USD). This group is made up of Southern European countries belonging to the PIGS group (Portugal, Italy, Greece, Spain) and countries referred to as emerging markets: from Central and Eastern Europe (including Poland - 8,000 USD; position 35), Asia (Turkey 7,000 USD; position 36) and South America (Mexico - 8,000 USD; position 40).

The third group i.e. the least developed countries consists of large countries from Europe and Asia: the Russian Federation - 500 USD (position 41), China - 200 USD (position 49), Indonesia - 150 USD (position 50), India - 100 USD (position 51) and South America: Argentina - USD 400 (position 42), Brazil - USD 300 (position 43).

In Figure 2 we present the average annual GDP growth rates in constant prices $(r)$ in 51 surveyed countries in 2005-2016. On the global scale, in the period 2005-2007 there was a high and improving economic situation, then a collapse and crisis in 2008-2010 followed by the overcoming of the crisis and return to better economic situation in 2011-2016. Individual countries experienced this in a significantly different way. The highest growth rates were achieved by: China $-10.4 \%$; India $-8.4 \%$; Indonesia $-6.1 \%$; Turkey $-5.0 \%$. Two countries had negative rates over this period: they were Greece at minus $1.9 \%$ and Italy with minus $0.2 \%$. Poland with the average annual growth rate of $4.1 \%$ came in $13^{\text {th }}$ place following Chile $(4.2 \%)$ and before Malta $(3.9 \%)$. Taking into account the average annual growth rate, we divided the surveyed countries into three groups:

- developing countries (29) $r=(+2+10 \%)$;

- countries in stagnation $(15) r=(+1+2 \%)$;

- countries in recession (7) $r=(-1+1 \%)$.

By far, the largest number of countries (29) have seen significant economic growth. Very important from the point of view of NSE are countries from the group of the least and moderately developed. Only 7 countries recorded the processes of stagnation and recession, mainly Japan $(0.07 \%)$ and selected European countries: Finland (0.08\%), Cyprus (1.0\%), Portugal (0.01\%), Italy $(-0.02 \%)$ and Greece $(-1.9 \%)$. 


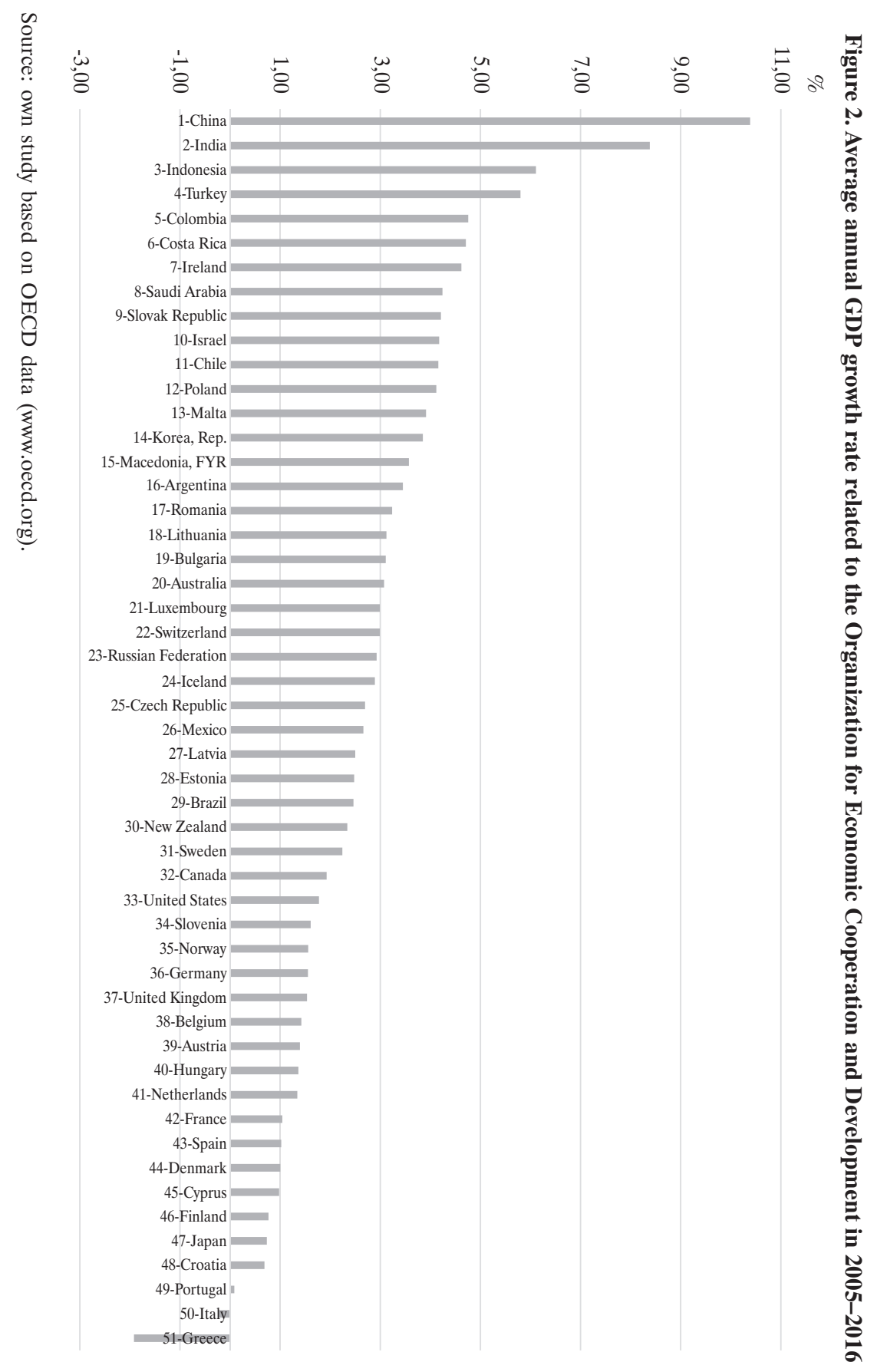


Taking into account two criteria, the level of GDP per capita at the beginning of the period (2005) and the average annual growth rate (y) in the period 2005-2016, we can separate 7 groups out of the 51 countries studied.

Table 1. Classification of OECD countries taking into consideration GDP per capita in 2005, economic growth rate (y) in 2005-2016 and long-term credit rating for liabilities expressed

in foreign currency by $\mathrm{S} \& \mathrm{P}$

\begin{tabular}{|c|c|c|c|c|}
\hline No. & $\begin{array}{c}\text { Group } \\
\text { of countries }\end{array}$ & Criterion & $\begin{array}{c}\text { Number } \\
\text { of } \\
\text { countries }\end{array}$ & $\begin{array}{c}\text { List of countries along with the issuer's } \\
\text { long-term rating regarding liabilities } \\
\text { expressed in a foreign currency } \\
\text { published by S\&P }\end{array}$ \\
\hline 1a & $\begin{array}{l}\text { Developed } \\
\text { fleeing }\end{array}$ & $\begin{array}{l}\mathrm{GDP}>30,000 \text { USD } \\
\mathrm{r}>2 \%\end{array}$ & 5 & $\begin{array}{l}\text { Luxembourg AAA, Iceland AA-, } \\
\text { Ireland A+, Sweden AAA, } \\
\text { Australia AAA }\end{array}$ \\
\hline $1 b$ & $\begin{array}{l}\text { Developed } \\
\text { stable }\end{array}$ & $\begin{array}{l}\mathrm{GDP}>30,000 \text { USD } \\
\mathrm{r}=(+1+2 \%)\end{array}$ & 11 & $\begin{array}{l}\text { Norway AAA, Switzerland AAA, } \\
\text { Denmark AAA, United States AA+, } \\
\text { United Kingdom AA, } \\
\text { Netherlands AAA, Austria AA+, } \\
\text { Belgium AA, Canada AAA, } \\
\text { France AA, Germany AAA }\end{array}$ \\
\hline $1 \mathrm{c}$ & $\begin{array}{l}\text { Developed } \\
\text { caught up }\end{array}$ & $\begin{array}{l}\text { GDP }>30,000 \text { USD } \\
\mathrm{r}=(-1+1 \%),\end{array}$ & 3 & Finland AA+, Japan A+, Italy BBB- \\
\hline $2 \mathrm{a}$ & $\begin{array}{l}\text { Moderately } \\
\text { developed } \\
\text { catching up }\end{array}$ & $\begin{array}{l}\mathrm{GDP}=30,000 \\
\mathrm{USD}-7,000 \mathrm{USD} \\
\mathrm{r}>2 \%\end{array}$ & 13 & $\begin{array}{l}\text { New Zealand AA, Israel A+, } \\
\text { South Korea AA, Malta A-, } \\
\text { Saudi Arabia A-, Czech Republic AA-, } \\
\text { Slovak Republic A+, Poland BBB+, } \\
\text { Mexico BBB+, Lithuania BBB+, } \\
\text { Chile AA, Latvia A-, Turkey BB }\end{array}$ \\
\hline $2 b$ & $\begin{array}{l}\text { Moderately } \\
\text { developed } \\
\text { stable }\end{array}$ & $\begin{array}{l}\text { GDP }=30,000 \\
\mathrm{USD}-7,000 \mathrm{USD} \\
\mathrm{r}=(+1+2 \%)\end{array}$ & 4 & $\begin{array}{l}\text { Spain BBB+, Slovenia A, } \\
\text { Hungary BBB-, Estonia AA- }\end{array}$ \\
\hline $2 \mathrm{c}$ & $\begin{array}{l}\text { Moderately } \\
\text { developed } \\
\text { caught up }\end{array}$ & $\begin{array}{l}\text { GDP }=30,000 \\
\text { USD }-7,000 \text { USD } \\
\mathrm{r}=(-1+1 \%)\end{array}$ & 4 & $\begin{array}{l}\text { Cyprus BB, Greece B-, Portugal BB+, } \\
\text { Croatia BB+ }\end{array}$ \\
\hline $3 a$ & $\begin{array}{l}\text { Least } \\
\text { developed } \\
\text { catching up }\end{array}$ & $\begin{array}{l}\text { GDP }<7,000 \text { USD } \\
\mathrm{r}>2 \%\end{array}$ & 11 & $\begin{array}{l}\text { Russian Federation BB+, } \\
\text { Argentina B-, Brazil BB, } \\
\text { Costa Rica BB-, Romania BBB-, } \\
\text { Bulgaria BB+, Colombia BBB, } \\
\text { Macedonia BB-, China AA-, } \\
\text { Indonesia BB+, India BBB- }\end{array}$ \\
\hline
\end{tabular}

Source: own calculations based on OECD data and Thomson Reuters Database.

By far the largest number of (11) highly developed countries was in the stable economies group with moderate economic growth (1-2\%). These countries include the United States and the main countries of the European 
Union (EU). All the least developed countries and the majority of moderately developed countries were in the group of catching-up countries (24), which seems to create good prospects for development, popularization, and practical use of NSE's ideas and concepts.

The diversified rate of economic growth resulted in changes in the classification of OECD countries in terms of GDP per capita. This classification for 2016 is presented in Figure 3. Luxemburg remained in the first place, but its GDP per capita increased to 100,000 USD. The reason for this growth, however, is not only a relatively high rate of economic growth of this country, but also the increase in the EUR to USD exchange rate. Switzerland came second (80,000 USD), despite achieving moderate growth. This is primarily the effect of the strengthening of the CHF against the USD. Two countries quit the group of the 19 most-developed countries: they were France (38,000 USD) and Italy (29,000 USD), replaced there by New Zealand (40,000 USD) and Israel (39,000 USD).

In the group of moderately developed countries in 2016, France ranked first (37,000 USD) followed by Italy (29,000 USD). Mexico (4,000 USD) and Turkey (5,000 USD) left the group while Argentina (12,000 USD) and Costa Rica (11,000 USD) joined it. Despite its relatively high rate of economic growth (4.1\%), Poland fell in this classification from position 33 to 38, mainly due to the increase in the USD exchange rate to PLN.

China's very high economic growth rate $(10.4 \%)$ lifted this country from position 49 to 46 . On the other hand, relatively high growth rate in India (8.4\%) and Indonesia (6.1\%) failed to move these countries from the last and the penultimate place on the list of the OECD richest countries.

As can be seen, national ratings of the S\&P agency in 2016 are strongly correlated with the division of OECD countries proposed by us in terms of GDP per capita into three groups. In the first group of the richest countries, apart from Italy, the grades are in the range of AAA- AA-. Italy's lower rating (BBB-) probably results from high public debt of this country (132\% of GDP). Relatively low ratings of Ireland $(\mathrm{A}+)$ and Iceland are the result of the recession of these two economies during the 2008-2009 crisis.

The ratings of countries in the moderately developed group are more diverse and, except for Greece (B-), located in the range between AA (New Zealand) and BB- (Cyprus). The lowest note of Greece results from the sovereign debt crisis of this country. The lowest ratings were attributed to countries from the least developed group and they are in the BB + (Russian Federation), BBB(India) range. 


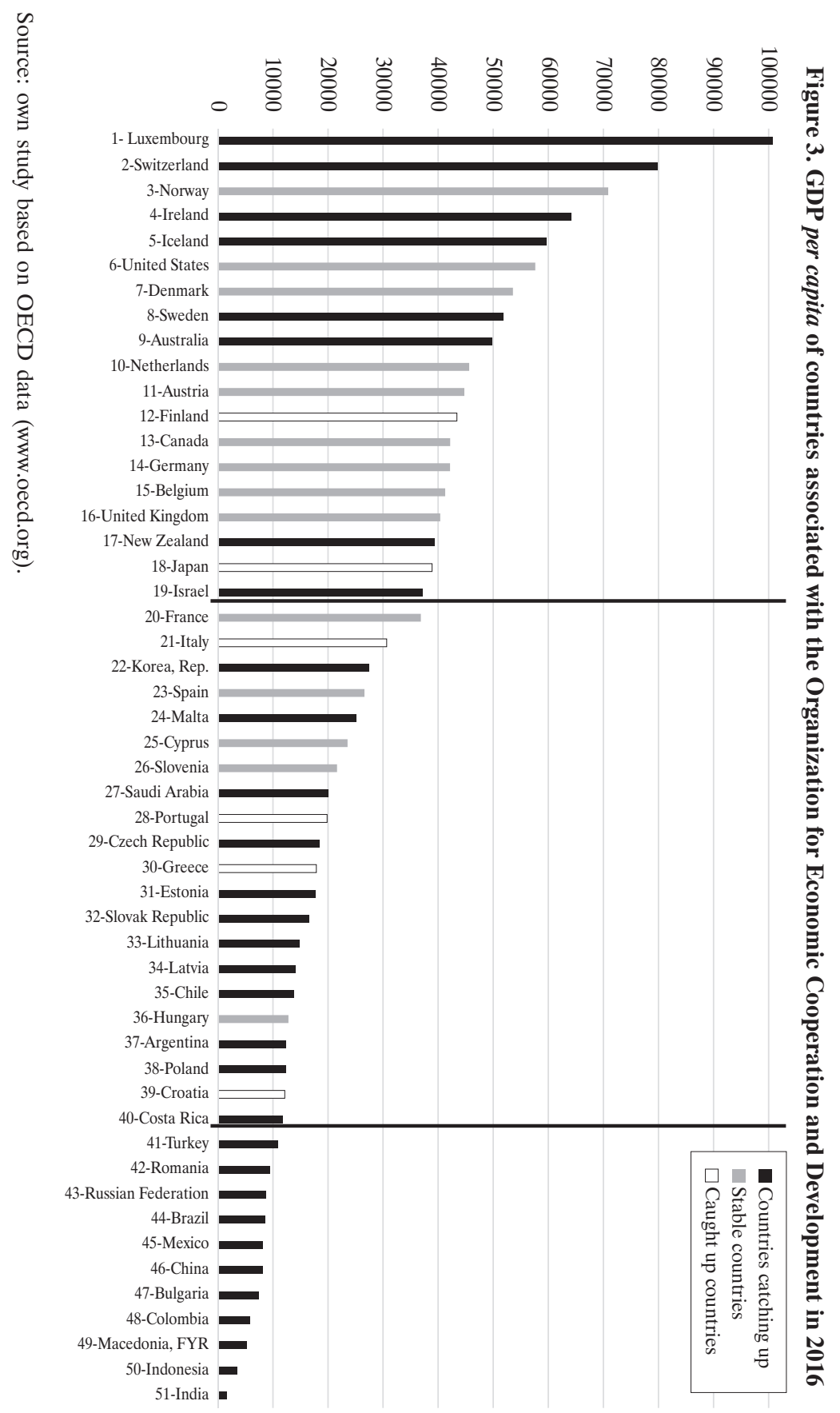

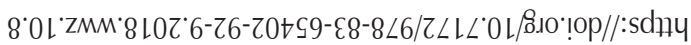




\section{Foreign Direct Investment}

In today's open and globalized economy, its development potential undoubtedly depends on the country's participation in international exchange on all commodity, labor, and financial markets. In particular, we will analyze the global capital flows within the so-called foreign direct investment (FDI). FDIs are compiled and published by central banks.

According to the definition, the IMF and OECD are a category of international investments made by a resident of one country (called „direct investor" or "parent company”) with the intention of exercising long-term control in another country's enterprise (called "direct investment enterprise” or „daughter company”). Long-term control means the existence of a long-term relationship between the direct investor and the daughter company. An important way of impact that gives the direct investor an effective voice in managing the enterprise, depends on the share of the direct investor in the daughter company's capital. The minimum threshold for the equity investor's direct investment in the daughter company is set at $10 \%$.

The FDI components are equity capital, reinvested earnings, and other capital. FDI's share capital is related to:

- purchase of shares, stocks or company assets,

- in-kind contribution, e.g. in the form of machines and devices,

- reinvested profits, part or all of the profits made (proportional to the share of the direct investor in the capital of the company), which was not paid in the form of a dividend.

Other capital is intra-corporate loans and transactions related to servicing this debt. The essence of FDI is the transfer not only of capital but also of labor (e.g. participation of representatives in the daughter company's management board) and knowledge (technological, marketing and organizational).

Foreign direct investment in national balance of payments accounts in the following terms:

- direct domestic investments abroad:

- inflow - shares acquired by residents abroad (shares, assets) + reinvested profits + increase in debt of foreign companies to residents;

- outflow - foreign shares sold by residents (shares - assets) + dividends paid to residents by foreign companies + debt repayment by foreign companies to residents;

- status (stocks) - shares held by residents at the end of the year (quarter) (shares, assets) + unpaid debts of foreign companies in relation to residents. 
- foreign direct investment in the country:

- inflow - shares acquired by foreign entities in the country (shares, assets) + profits reinvested by foreign entities in the country + increase in the debt of domestic companies in relation to foreign entities;

- outflow - shares (stocks, assets) sold by foreign entities + dividends paid by residents to foreign entities + repayment of residents' debt to foreign companies;

- status (stocks) - shares held by foreign entities in the country (shares, assets) + non-paid debts of residents towards foreign entities.

According to the OECD and World Bank definition, in net international statistics the net inflow balance under FDI is the value of direct investments made by foreign investors in the reporting economy. The net outflow balance is the value of direct foreign investments made by residents of the reporting economy on external economies. Direct investments, also referred to as direct investments in the reporting economy, include all liabilities and assets transferred between resident institutions making direct investments and their direct investors. It also includes transfers of assets and liabilities between resident and non-resident enterprises if the ultimate controlling parent is not resident.

External direct investments, also referred to as direct investments abroad, include assets and liabilities transferred between direct investors and their direct investment enterprises. They include transfers of assets and liabilities between resident and non-resident enterprises if the ultimate controlling parent is resident. External direct investments are also referred to as direct investments abroad.

Data on FDI flows are also presented as the balance (FDI net): the difference between the inflow of capital to the reporting country and the outflow of capital from the reporting country (receivables minus liabilities between direct investors and their foreign affiliates). The decrease in the net asset value or the increase in net liabilities is recorded as loans, while the net asset increases or the net decrease in liabilities are recorded as charges. Hence, FDI flows with a negative sign indicate that at least one of the FDI components is negative and is not compensated by positive values of other components. These are cases of reverse investment or disinvestment.

The FDI database published by the OECD covers the value of the annual inflow and outflows of investments to and from individual countries in USD, the value of the annual inflow and outflow of capital in the form of FDI and the share of FDI inflow stream in host countries' GDP and the share of FDI outflow in GDP of countries investing. 
Figure 4. The inflow of direct investments in USD billion

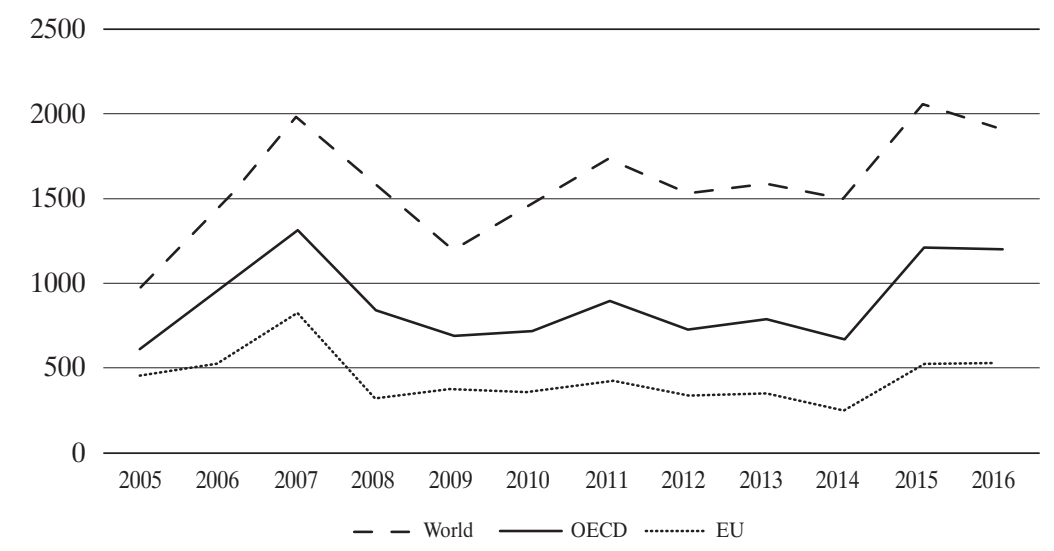

Source: own study based on OECD data (www.oecd.org).

Figure 5. Outflow of direct investment in USD billion

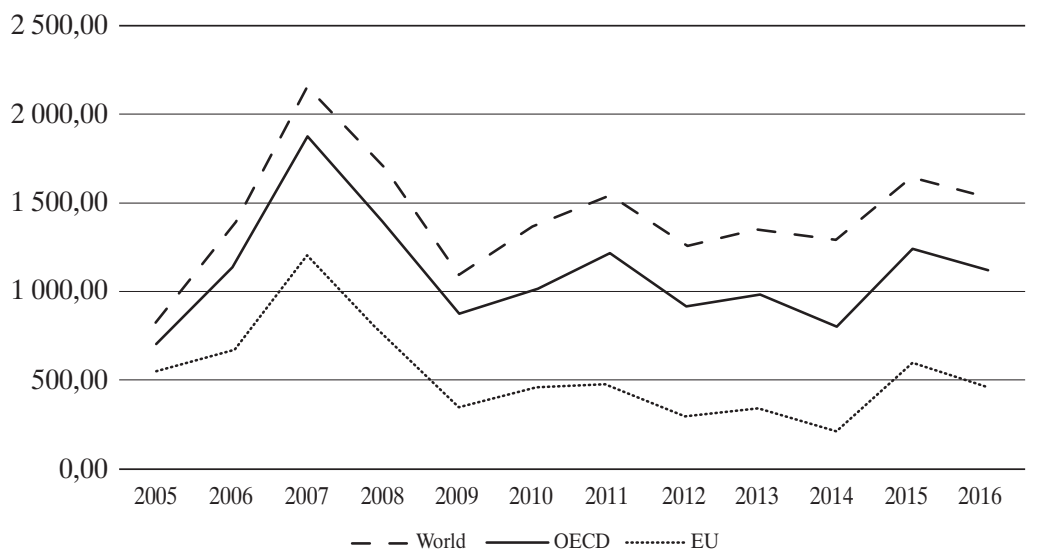

Source: own study based on OECD data (www.oecd.org).

The OECD countries have the largest share in FDI inflow and outflow of capital, while their share in the annual outflow amounts to about $90 \%$ of global outflows, while in annual FDI inflows it is only $62 \%$. It follows from this that OECD countries are more direct providers of direct investments to other countries, while to a lesser extent they are the destination of global direct investments.

L. Alfaro and J. Chauvin (2017) proved in their study that developing economies are growing as a result of an increase in direct investment, at the 
same time creating opportunities and threats for host countries. In their analysis, they used macroeconomic variables (GDP growth rate, aggregated production, exports) and microeconomic ones (positive external effects of side effects, links and reallocation of capital). Economic benefits are diversified in relation to the level of economic development due to the inflow of direct investments. Foreign companies invest capital more often in less-developed economies than in developed economies, where they can raise funds at the local level. Both types of economies are likely to benefit from wage increases and export due to the presence of foreign capital, although potentially it will occur through different channels. In underdeveloped economies, export can increase because foreign companies have smaller financial constraints and can afford a fixed cost of export. In developed economies, instead, export can result from the fact that foreign companies avoid greater competition in local markets. Greater microeconomic benefits resulting from the spread of foreign direct investment, positive links, and competitive pressure are more likely in economies with well-developed financial markets, where local companies can respond to these opportunities and threats due to increased competition through investments that increase their productivity.

Figure 6. Inflow of direct investment as a percentage of GDP

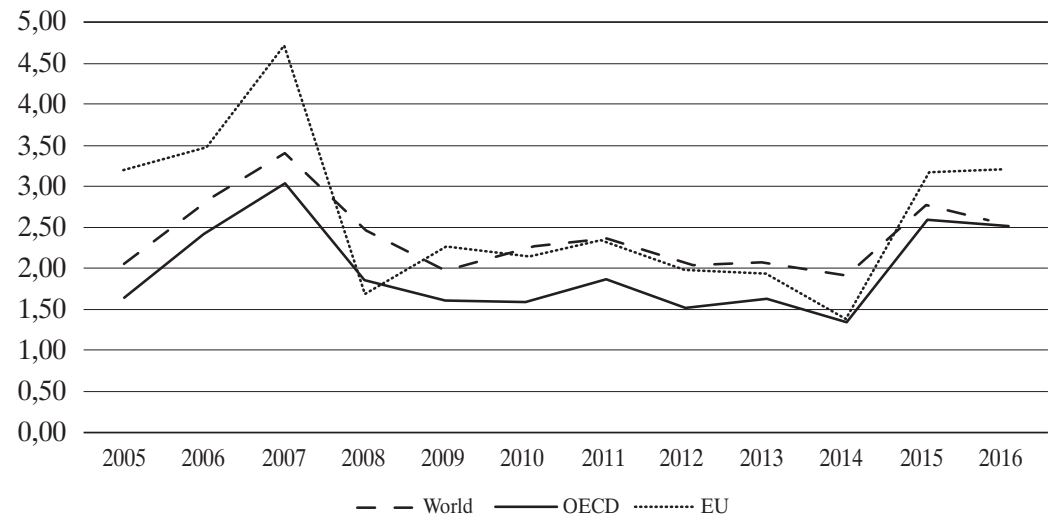

Source: own study based on OECD data (www.oecd.org).

In Figure 6, we show annual inflow streams, and in Figure 7, annual FDI outflows on the global, OECD, and EU scale as a percentage of GDP (respectively: world, OECD, and EU). The FDI within the EU is the most important in relation to GDP. The value of direct investments that flowed into the EU in 2007 was $4.60 \%$ of their GDP, while the value of FDI of EU 
residents abroad accounted for $7.00 \%$ of GDP that year. Thus, EU residents are, to a larger extent, direct investors than recipients of foreign investments. For the OECD countries, the same indicators in 2007 were respectively: FDI inflow $-3.10 \%$ of GDP; FDI outflow $-4.20 \%$ of GDP. So, again, residents of these countries to a greater extent invest abroad than act as beneficiaries of foreign investments. However, the difference is much smaller compared to the EU.

Figure 7. Inflow of direct investment as a percentage of GDP

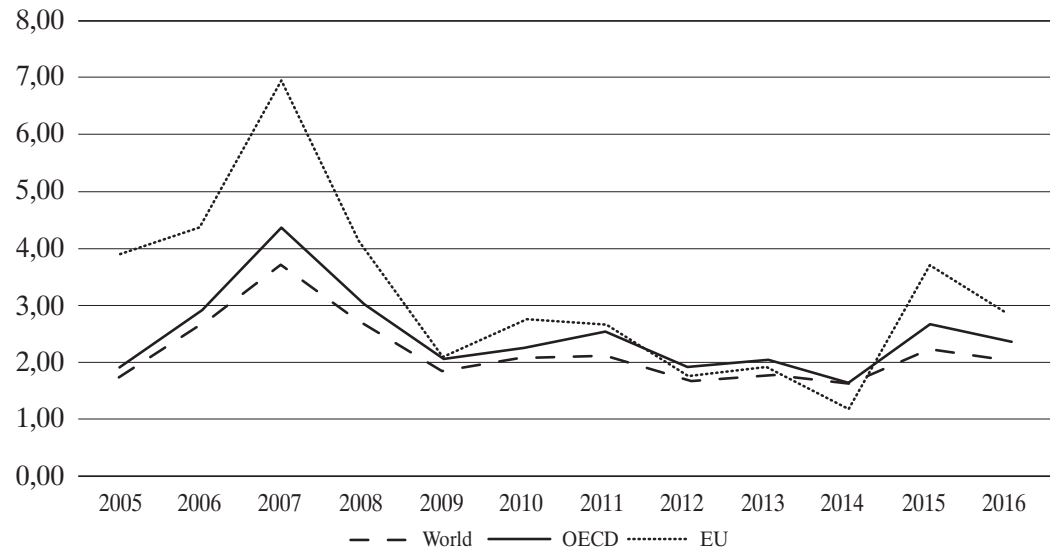

Source: own study based on OECD data (www.oecd.org).

Figure 8. Inflow of direct investment in three groups of OECD countries, taking into account the level of economic development measured by GDP per capita in USD million

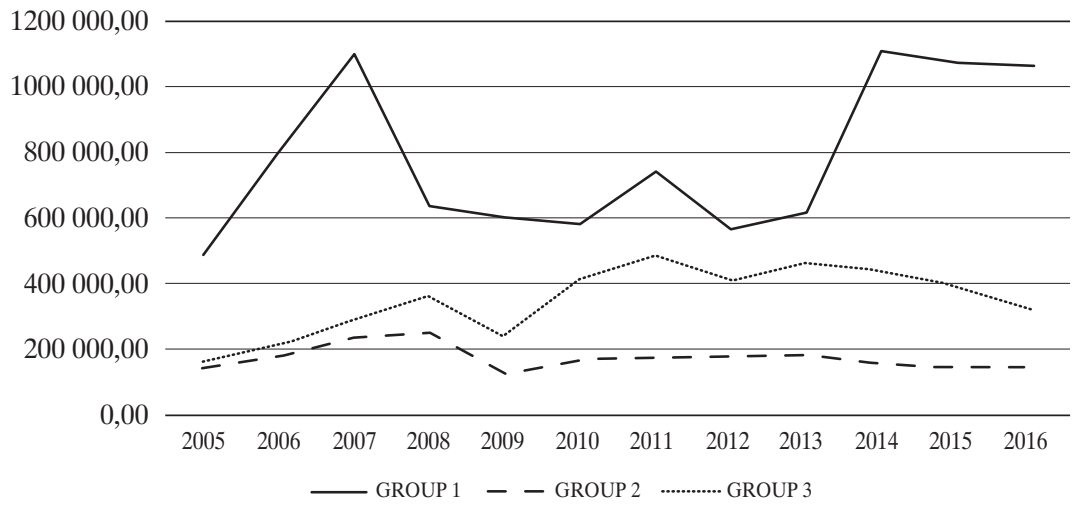

Source: own study based on OECD data (www.oecd.org). 
Figure 9. Outflow of direct investment in three groups of OECD countries, taking into account the level of economic development measured by GDP per capita in USD million

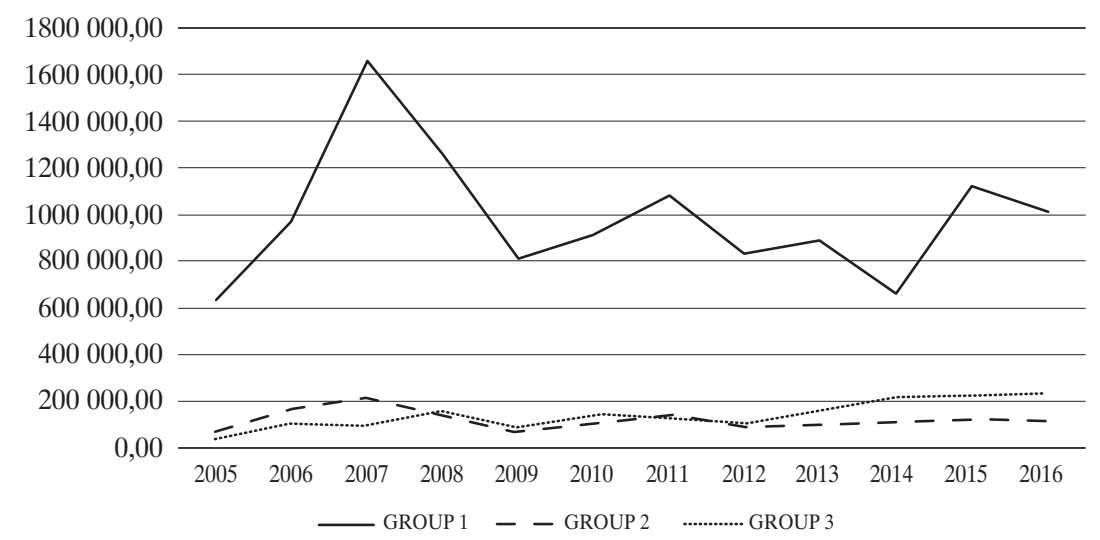

Source: own study based on OECD data (www.oecd.org).

Figure 8 shows the FDI inflow, and Figure 9 shows the outflow of capital from three groups of OECD countries highlighted in the first part of the article (highly developed, moderately developed, and least developed). As before, all streams are reported for the period 2005-2016. It is worth noting that the inflow and outflow of capital under FDI is very sensitive to the global business cycle, phenomenon that cannot be seen in the group of moderately and least developed countries. The FDI inflow increased in the period 2005-2007 from approximately USD 500 billion to USD 1,100 billion. The value of direct investments of residents of OECD countries abroad in 2007 amounted to USD 1.6 billion, which accounted for $84 \%$ of direct investments of the entire OECD and $71 \%$ of global direct investments. The inflow of FDI to OECD countries amounted to USD 1.1 trillion that year, which accounted for $85 \%$ of the FDI inflow to the entire OECD and 55\% of global FDI values that year. The above indicators show that FDI has the primary meaning within the OECD between residents of the 19 most developed countries in the world. Residents of these countries are net exporters to other countries, which is reflected in the negative balance of FDI in this group of countries, shown in Figure 10. In the opposite situation are moderately and least developed countries that have positive FDI balance. A special beneficiary of FDI is the group of the least developed countries, whose FDI balance is almost twice as high as in the group of moderately developed countries. 
In their study R. Caesar and O.R. Escobar (2015) analyzed the links between foreign direct investment and institutional distance ${ }^{3}$. They verified how the institutional distance affects foreign direct investment and showed that institutional distances reduce the likelihood that the company will invest in a foreign country, which is also related to the size of the investment it will make. A study conducted on OECD data indicates that FDI activity decreases with the institutional distance. In addition, they note that companies from developed economies are easier to adapt to institutional distance than companies from developing economies.

Figure 10. Balance of direct investment in three groups of OECD countries, taking into account the level of economic development measured by GDP per capita

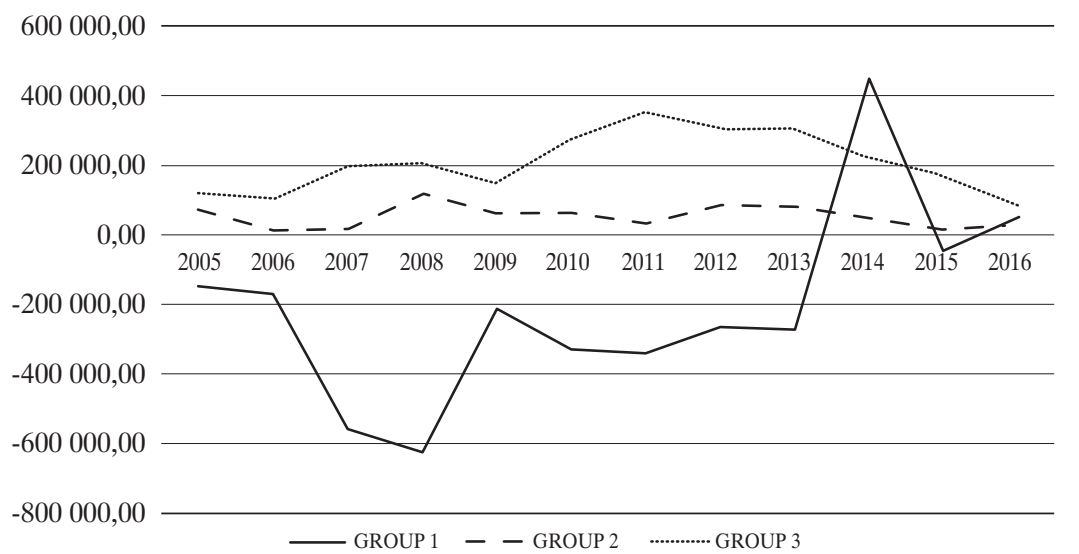

Source: own study based on OECD data (www.oecd.org).

Table 2. The inflow of direct investments from groups I, II and III to groups I and II in USD million

\begin{tabular}{|c|c|c|c|c|c|c|}
\hline $\begin{array}{c}\text { Accepting } \\
\text { countries }\end{array}$ & \multicolumn{2}{|c|}{ GROUP I } & \multicolumn{2}{c|}{ GROUP II } & \multicolumn{2}{c|}{ GROUP III } \\
\hline $\begin{array}{c}\text { Sending } \\
\text { countries }\end{array}$ & GROUP I & GROUP II & GROUP I & GROUP II & GROUP I & GROUP II \\
\hline 2005 & 68341 & 22728 & 11933 & 3156 & 174 & 144 \\
\hline 2006 & 50024 & 20339 & 5902 & 2768 & 3206 & 83 \\
\hline 2007 & 123325 & 28132 & 10864 & 5695 & 906 & 35 \\
\hline 2008 & 60463 & 24204 & -11864 & 6570 & 279 & 282 \\
\hline 2009 & 69549 & 20932 & 2693 & 6074 & -1619 & 329 \\
\hline
\end{tabular}

3 Differences between regulations and regulating institutions. 
continued Table 2

\begin{tabular}{|c|c|c|c|c|c|r|}
\hline $\begin{array}{c}\text { Accepting } \\
\text { countries }\end{array}$ & \multicolumn{2}{|c|}{ GROUP I } & \multicolumn{2}{c|}{ GROUP II } & \multicolumn{2}{c|}{ GROUP III } \\
\hline $\begin{array}{c}\text { Sending } \\
\text { countries }\end{array}$ & GROUP I & GROUP II & GROUP I & GROUP II & GROUP I & GROUP II \\
\hline 2010 & 91608 & 25737 & 2507 & 4938 & -98 & 230 \\
\hline 2011 & 355466 & 78538 & 16896 & 7327 & 1589 & -2103 \\
\hline 2012 & 337360 & 59715 & 15593 & 3251 & 3412 & 303 \\
\hline 2013 & 637943 & 102548 & 77210 & 5694 & 12347 & 1255 \\
\hline 2014 & 398755 & 78380 & 31463 & 13313 & 19822 & 1272 \\
\hline 2015 & 870877 & 40743 & 19141 & 10394 & 1575 & 395 \\
\hline 2016 & 709703 & 116074 & 25188 & 16292 & 7451 & 1071 \\
\hline
\end{tabular}

Source: own study based on OECD data (www.oecd.org).

Table 3. Outflow of direct investments from groups I, II and III to groups I, II and III in million USD

\begin{tabular}{|c|r|r|r|r|r|r|}
\hline $\begin{array}{c}\text { Accepting } \\
\text { countries }\end{array}$ & \multicolumn{2}{|c|}{ GROUP I } & \multicolumn{2}{c|}{ GROUP II } & \multicolumn{2}{c|}{ GROUP III } \\
\hline $\begin{array}{c}\text { Sending } \\
\text { countries }\end{array}$ & GROUP I & GROUP II & GROUP I & GROUP II & GROUP I & GROUP II \\
\hline 2005 & 93999.50 & 83.32 & 24061.65 & 425.89 & 7659.71 & 222.50 \\
\hline 2006 & 131022.97 & 355.27 & 30079.08 & 676.51 & 10372.79 & 134.14 \\
\hline 2007 & 198611.91 & 467.78 & 26477.75 & 1142.08 & 20750.17 & 288.89 \\
\hline 2008 & 87543.86 & 413.61 & 36568.71 & 925.55 & 19596.49 & -83.17 \\
\hline 2009 & 143029.68 & -63.04 & 17421.18 & 2170.64 & 4487.36 & 280.24 \\
\hline 2010 & 129460.87 & 1139.48 & 19266.27 & -139.63 & 6712.58 & $-3,75$ \\
\hline 2011 & 405668.24 & 42001.20 & 21922.29 & 3332.72 & 10119.23 & 194.26 \\
\hline 2012 & 314797.58 & 1647.07 & 35197.69 & 2186.47 & 14596.41 & 428.15 \\
\hline 2013 & 567517.90 & 7785.97 & 79522.83 & 8911.37 & 27716.08 & 878.87 \\
\hline 2014 & 491038.61 & 24053.40 & 59599.13 & 21673.86 & -96.58 & 971.46 \\
\hline 2015 & 774445.08 & 8577.26 & 36172.76 & 8936.24 & 15702.54 & 1980.20 \\
\hline 2016 & 676821.75 & 97956.83 & 72499.14 & 6566.18 & 9926.59 & 33.81 \\
\hline
\end{tabular}

Source: own study based on OECD data (www.oecd.org).

Research of M. Irandoust (2016) conducted among the Baltic countries between FDI and structural changes has shown that by promoting growth and structural reforms, beneficiary countries can encourage the inflow of foreign 
direct investment, which in turn may affect their growth. They also indicated the existence of a feedback between these two variables.

The analysis conducted is consistent with the assumptions of the new structural economics (Lin, 2010; 2012). It turned out that, depending on the level of economic development, the optimal industrial structure is changing. The form of the inflow of direct investment funds from the point of view of the economy is also changing. In the current situation, it can be presumed that, depending on the level of economic development, countries should invest in both "soft" and "hard" infrastructure. At the same time, according to the assumption of the theory, it can be presumed that in the process of continuity there is a continuous economic growth presented by us as the "race of countries" theory. The change depending on the type of sector in which direct investments are made causes gradual economic growth. Therefore, countries should adapt their investments in a given sector depending on the level of their economic development. In addition, the impact of the financial crisis on the allocation of direct investment in individual economies shows that at each given stage of development, the market is the basic mechanism for effective allocation of resources. As a result, along with the economic growth, according to the New Structural Economics, the economies require industrial modernization and appropriate improvements in the "hard" and "soft" infrastructure at every stage. Such modernization entails significant external effects on the transaction costs of companies and returns on capital investments. Therefore, in addition to an effective market mechanism, the government should play an active role in facilitating industrial modernization and infrastructure improvements.

The research conducted indicates two economies that are especially interesting in this respect, i.e. China and India, both peculiar due to their size and very fast growth. R. Dekle and G. Vandenbroucke (2012, p. 119-135) investigated the structural transformation in China in 1978-2003. They found that the diversified sectoral increase in productivity and the reduction in the relative size of the Chinese government caused most of the structural transformation but slowed down the movement in agriculture. V. Rubina (2012, p. 163-177) investigated the structural transformation in India in 1980-2005 and found that the growth was fastest in services. She proved that the three-sector model could take into account changes in sectoral value added, but not in employment shares. C.M. Betts et al. (2011), M. Sposi (2011) and Teignier (2012) argue that international trade has accelerated the transition of the economy from agriculture to industry and services. Teignier (2012) has proven that the effect of international investment would have played an even greater role if South Korea did not introduce a policy of agricultural protection at the same time. 
Work of D.W. Jorgenson and M.P. Timmer (2011, p. 1-29) based on the study of the European Union, Japan, and the USA shows a significant heterogeneity of services. Finance and business services are characterized by low productivity growth and increase the share in employment and GDP, while distribution services have rapid increase in productivity and constant participation. M. Duarte and D. Restuccia (2010, p. 129-173) studied the differences between traditional ${ }^{4}$ and non-traditional services. In the case of traditional services, they notice that the relative price increases and the real share of expenses decreases with revenues, while in the case of non-traditional services the opposite occurs. D. Lagakos and M.E. Waugh (2013, p. 948-980) argue that the inclusion of heterogeneous quality of work in different sectors proves that poor countries seem to have particularly low productivity in agriculture.

B. Herrendorf, R. Rogerson, A. Valentinyi (2014, p. 855-941) indicate that inadequately selected structural policies may distort the allocation of resources in various sectors. In accordance with the new structural economics, structural transformation should strive to use state intervention to develop specific sectors with the greatest potential for development (Ketels, 2017). Assumptions about profitability in neoclassical economics can be eased by analyzing issues of development and transformation in socialist, transformational, and developing economies (Lin, 2015).

Figure 11. Balance of direct investment by sector in the first group of countries in USD million

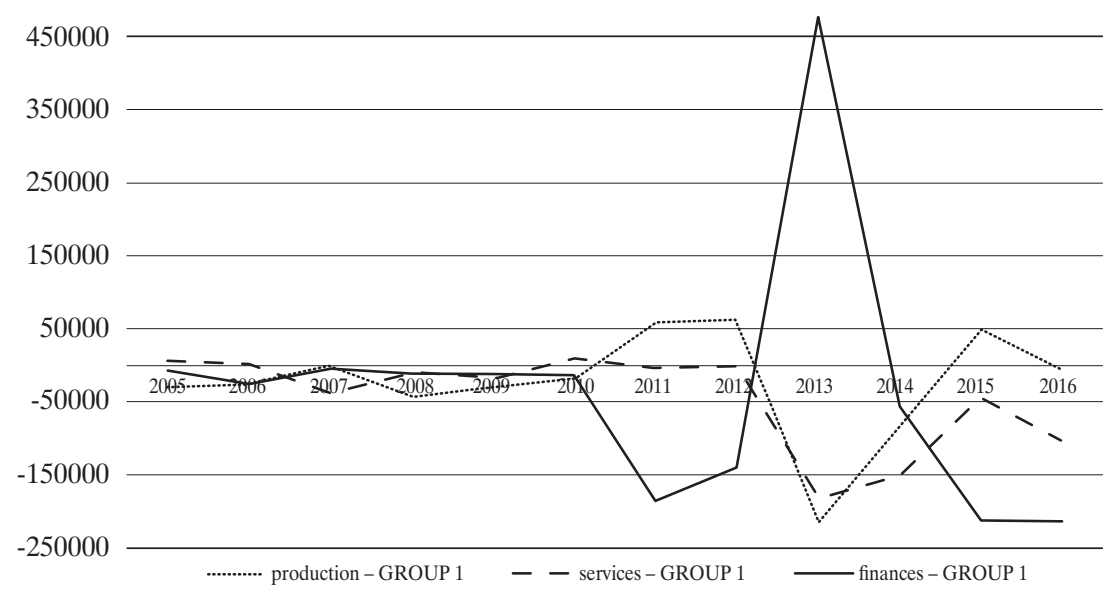

Source: own study based on OECD data (www.oecd.org).

4 I.e. traditional services such as home services and education, health, housing, and nontraditional services including communication, transport, insurance and financial services as well as recreational and cultural services. 
Figure 12. Balance of direct investment by sector in the second group of countries in USD million

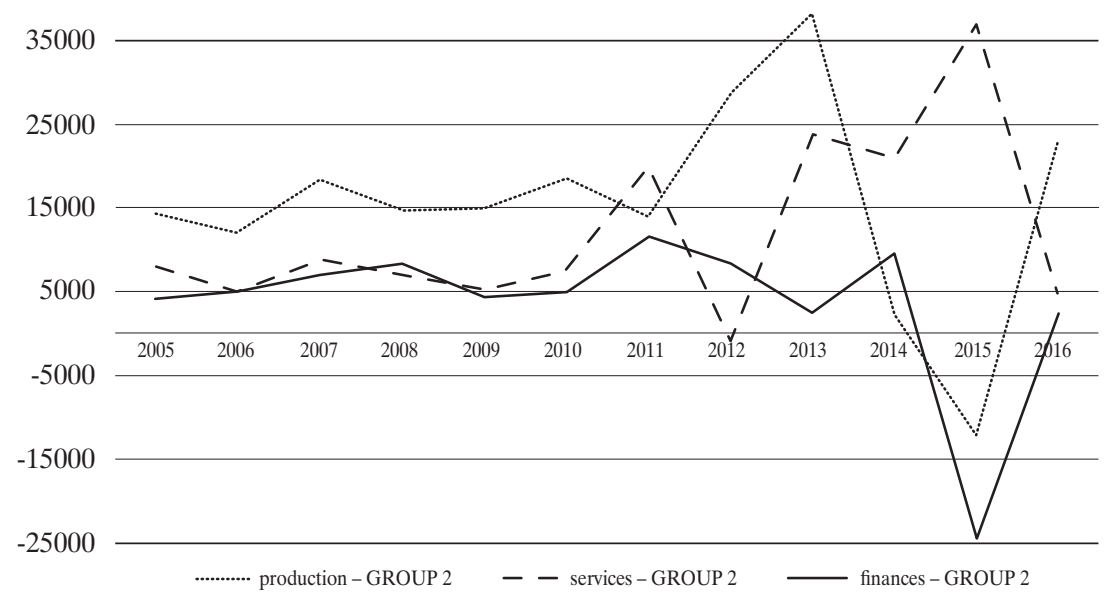

Source: own study based on OECD data (www.oecd.org).

Next, it was decided to verify the mutual relations between the balance of direct investment and the real rate of GDP growth and vice versa. To verify this relationship, annual data from the World Bank for the years 1970-2017 was collected for 165 countries. Static panel models were used for the study. The Hausman-Breusch-Pagan test was used to verify the correctness of the model selection. The choice of the panel model was dictated by simultaneously having the features of cross-sectional data, i.e. data for countries and time series. The model presenting the impact of the real GDP growth rate on the balance of direct investments to GDP is as follows:

$$
f d i_{i t}=\alpha+p k b_{i t}+u_{i t}+e_{i t}
$$

$f d i_{i t}$ - the ratio of direct investment to GDP in the $i$-th country in period $t$, $p k b_{i t}$ - real GDP growth rate of the $i$-th country in period $t$, $\alpha$ - constant,

$u_{i t}$ - a random error containing time-constant unobserved characteristics, $e_{i t}$ - purely random error.

The model revealing the impact of the direct investment balance on the real GDP growth rate is presented below:

$$
p k b_{i t}=\alpha+f d i_{i t}+u_{i t}+e_{i t}
$$


Table 4 presents the results of the estimation.

Table 4. Results of estimation of the impact of the real GDP growth rate on the balance of direct investment (1) and the balance of direct investments on the real GDP growth rate

\begin{tabular}{|c|c|c|c|c|}
\hline \multirow{2}{*}{ Dependent variable } & \multicolumn{2}{|c|}{ FDI net (1) } & \multicolumn{2}{|c|}{ Real GDP growth rate (2) } \\
\hline & Coef. & $P>$ the & Coef. & $P>$ the \\
\hline \multirow[t]{2}{*}{ Independent variable } & .123695 & 0.000 & .0306341 & 0.000 \\
\hline & 3.500842 & 0.000 & 3.704615 & 0.000 \\
\hline Number of observations & \multicolumn{2}{|c|}{5911} & \multicolumn{2}{|c|}{5911} \\
\hline Number of groups & \multicolumn{2}{|c|}{165} & \multicolumn{2}{|c|}{165} \\
\hline F test & \multicolumn{2}{|c|}{0.0000} & \multicolumn{2}{|c|}{0.0000} \\
\hline Hausman & \multicolumn{2}{|c|}{0.1306} & \multicolumn{2}{|c|}{0.1947} \\
\hline $\mathrm{BP}$ & \multicolumn{2}{|c|}{0.0000} & \multicolumn{2}{|c|}{0.0000} \\
\hline \multicolumn{5}{|l|}{$\mathrm{R}$ squared } \\
\hline Inside & \multicolumn{2}{|c|}{0.0034} & \multicolumn{2}{|c|}{0.0034} \\
\hline Between & \multicolumn{2}{|c|}{0.0240} & \multicolumn{2}{|c|}{0.0240} \\
\hline Total & \multicolumn{2}{|c|}{0.0070} & \multicolumn{2}{|c|}{0.0070} \\
\hline Model & \multicolumn{2}{|c|}{ with variable effects } & \multicolumn{2}{|c|}{ with variable effects } \\
\hline
\end{tabular}

Legend: number of groups - number of countries analyzed; test F - Fisher test; Hausman - Hausman test; BP - Breusch - Pagan test; R squared - corrected: inside - corrected inside a group of countries; between - corrected between groups of countries; total - total adjusted.

Source: own study.

The results of the estimation carried out for the Hausman test suggest the correctness of the use of a static panel model with variable effects. However, the results obtained for the Bresuch-Pagan test indicate the appropriateness of using a panel model for the linear model in both cases. Being aware of the poor fit of the model, we do not perform a direct analysis of the results. Our goal was only to verify the significance of mutual dependencies between the balance of direct investment and the real rate of GDP growth and vice versa. The study proved a statistically significant relationship between the two variables. The low level of model matching should be explained by the impact of other significant factors affecting both the balance of direct investment and the real GDP growth rate. The simulation results obtained are consistent with research by C.K. Volos, I.M. Kyprianidis, I.N. Stouboulos (2015, p. 1-7).

K. Dellis, D. Sondermann, I. Vansteenkiste (2017) pointed to the impact of structural changes, such as labor costs, the size of the target market (according to its value), economic activity, openness of trade of the beneficiary country and its tendency to tax. S. Estrin and M. Uvalic (2013) proved that, taking into 
account the size of an economy, distance, institutional quality and prospects of EU membership, the countries of the Western Balkans are characterized by a lower inflow of foreign direct investment. These issues have a high political significance for the Balkan economies.

We are fully convinced that foreign direct investment is not the only or even the main factor influencing economic growth, as well as that the rate of economic growth does not fully determine the inflow and outflow of these investments. This is evidenced by low multiple correlation coefficients in both presented models. Our goal, however, was not to completely explain the determinants of these two variables - for that purpose multifactorial models should be used. However, both univariate models prove the hypothesis of the existence of positive feedback between these variables. The inflow of direct investments positively affects the rate of economic growth, and economic growth encourages foreign investors to invest. This means that FDI operate pro-cyclically. They support economic growth, but also deepen recessions and decrease in GDP. If the slowdown or decline in the economic growth rate occurs as a result of internal or external shocks, the reaction of foreign investors deepens this decline. This phenomenon occurred very clearly in 2018 in the case of Argentina and Turkey.

This phenomenon has already been observed in the relation of bank loans and economic growth. Under Basel III, special counter-cyclical capital buffers were introduced to calculate the solvency coefficient, to counter the pro-cyclical nature of loans. However, unlike the banking sector, FDIs are not regulated by countries of origin or host countries.

\section{References}

Alfaro, L. and Chauvin, J. (2017). Foreign Direct Investment, Finance, and Economic Development. Harvard Business School Working Papers.

Betts, C.M., Giri, R. and Rubina, V. (2011). Trade, Reform, and Structural Transformation in South Korea. University of Southern California Working Paper.

Cezar, R. and Escobar, O.R. (2015). Institutional Distance and Foreign Direct Investment. Banque de France, December.

Dekle, R. and Vandenbroucke, G. (2012). A Quantitative Analysis of China's Structural Transformation. Journal of Economic Dynamics and Control, 36, 119-135.

Dellis, K., Sondermann, D. and Vansteenkiste, I. (2017). Determinants of FDI inflows in advanced economies: Does the quality of economic structures matter? European Central Bank Working Paper, No. 2066.

Duarte, M. and Restuccia, D. (2010). The Role of the Structural Transformation in Aggregate Productivity. Quarterly Journal of Economics, 125, 129-173. 
Estrin, S. and Uvalic, M. (2013). Foreign direct investment into transition economies: Are the Balkans different? London School of Economics Europe in Questions Working Paper, No. 63.

Herrendorf, B., Rogerson, R. and Valentinyi, A. (2014). Growth and Structural Transformation. Handbook of Economic Growth, 2, 855-941.

https://data.oecd.org

Irandoust, M. (2016). Structural changes, FDI, and economic growth: evidence from the Baltic states. Journal of Economic Structures, 5(14).

Jorgenson, D.W. and Timmer, M.P. (2011). Structural Change in Advanced Nations: A New Set of Stylised Facts. Scandinavian Journal of Economics, 113, 1-29.

Ketels, C. (2017). Structural transformation: a competitiveness-based view. African Development Bank Group Working Papers, No. 258.

Lagakos, D. and Waugh, M.E. (2013). Selection, Agriculture, and Cross-Country Productivity Differences. The American Economic Review, 103(2), 948-980.

Lin, J.Y. (2010). New Structural Economics A Framework for Rethinking Development. World Bank Policy Research Working Paper, No. 5197.

Lin, J.Y. (2012). New Structural Economics. A Framework for Rethinking Development and Policy. World Bank.

Lin, J.Y. (2017). New Structural Economics and 2017 industrial policies catching-up economics. W: J.Y. Lin, A.Z. Nowak (ed.), New Structural Economics for less advanced countries. Warszawa: Wydawnictwo Naukowe Wydziału Zarządzania UW.

Lin, J.Y. (2015). The Washington Consensus revisited: a new structural economics perspective. Journal of Economic Policy Reform, 18.

Rubina, V. (2012). Can Total Factor Productivity Explain Value Added Growth in Services. Journal of Development Economics, 99, 163-177.

Sposi, M. (2011). Evolving Comparative Advantage, Structural Change, and the Composition of Trade. University of Iowa Working Paper.

Teignier, M. (2012). The Role of Trade in Structural Transformation. Universidad de Alicante Working Paper.

Volos, C.K., Kyprianidis, I.M. i Stouboulos, I.N. (2015). The Effect of Foreign Direct Investment in Economic Growth from the Perspective of Nonlinear Dynamics. Journal of Engineering Science and Technology Review, 8(1), 1-7. 